\title{
Research of Hybrid Adhesive Bonds with Filler Based on Coffee Bean Powder Exposed to Cyclic Loading
}

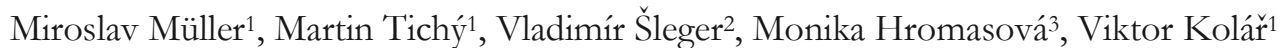 \\ ${ }^{1}$ Department of Material Science and Manufacturing Technology, Faculty of Engineering, Czech University of Life \\ Sciences Prague. Kamycka 129, 16500 Prague 6-Suchdol. Czech Republic: muller@tf.czu.cz, martinti- \\ chy@tf.czu.cz, vkolar@tt.czu.cz \\ ${ }^{2}$ Department of Mechanical Engineering, Faculty of Engineering, Czech University of Life Sciences Prague. \\ Kamycka 129, 16500 Prague 6-Suchdol. Czech Republic.; sleger@tt.czu.cz \\ 3Department of Electrical Engineering and Automation, Faculty of Engineering, Czech University of Life Sciences \\ Prague. Kamycka 129, 16500 Prague 6-Suchdol. Czech Republic.; hromasova@tf.czu.cz
}

Technology of adhesive bonding belongs to prospective bonding methods. The limit of adhesive bonds is cyclic loading which usually significantly decreases the service life of adhesive bonds and causes deformation of adhesive and cohesive bonds inside of adhesives. The article deals with the research of adhesive bonds exposed to cyclic loading. The aim of research was establishing an influence of the filler based on meshed coffee beans waste added into two-component epoxy matrix for bonding. The differences of mechanical properties of adhesive bonds with filler based on meshed coffee beans waste were evaluated at static and cyclic loading with 1000 cycles at first interval loading between 5 to $30 \%$ and second interval $5 \%$ to $70 \%$ of the static shear tensile strength.

Keywords: quasi-static test, mechanical properties, service-life, secondary waste product, composite material, SEM

\section{Introduction}

A relevant method of bonding various materials is the adhesive bonding technology [1,2]. This technology came through a dynamical development until the Second World War. The trend of recent years is creation of hybrid adhesive layers $[3,4]$ i.e. the layer is modified by adding biologic or synthetic fabric and particles into adhesives as fillers. The fillers are added into adhesive for long time, but they were mainly synthetic fillers based on e.g. ballotine, aluminium particles etc. [5-7]. It is necessary to eliminate fillers which decrease the strength of adhesives.

Another recent trend in the adhesive bonding technology is bonding of metallic and composite materials [8].

An important limit of the adhesive bonding technology is a cycling loading of bonds which causes irreversible damage of adhesive and cohesive connections in adhesive bonds [9-12]. This negative condition caused by cyclic loading arises even at low loading values [9-13]. Messler [14] described in his research that the negative effect of cyclic fatigue can be minimized by adding appropriate filler. The static mechanical properties of epoxy adhesives and adhesive bonds are well written in literature [15], but the properties of adhesives exposed to cyclic (quasi-static) loading are not entirely described.

A relevant influence at the quasi-static loading are bonding material properties $[8,16]$. The higher stiffness of bonding material leads to higher value of the shear strength of adhesive bonds [8].

Raykhere et al. [17] state result of their experiments that the quasi-static tests are not dependent on combination of bonding materials.

The fillers for composite materials are used in a synthetic and natural form. Especially natural based fillers are important. They have good mechanical properties, come from renewable sources, are nontoxic and have low cost $[18,19]$. Fillers come often from secondary waste products. The traditional biologic filler are mainly fibre reinforcements - sisal, coconuts, flax, jute, cotton etc. [20-26]. Less tradition materials are coffee bean powder. Suaduang et al. and Muniappan et al. dealt with utilization of spent coffee as filler into composite materials [18,19]. Muniappan et al. state that a powder from coffee bean is one of the most common natural substances of filler. $\mathrm{Mu}$ niappan et al. dealt with spent coffee from hotels and state that it is observed that with increase in mass fraction of coffee bean powder in the epoxy matrix, fracture toughness gets increased along with increase in ultimate load and ultimate stress up to $25 \%$ [19].

Coffee is a global foodstuff determined for drink production $[27,28]$. A waste is produced during processing of coffee beans, i.e. unused waste beans which are a source of lignocellulosic material rich in bioactive compounds [27]. The current trend is a regeneration 
of biomass from coffee [27]. It is especially important to focus on value-added applications [27]. It is the composite materials based on biological reinforcement [9].

The research aim was to find out an influence of filler based on meshed waste coffee beans added into two-epoxy matrix for adhesive bonding. Changes in mechanical properties were evaluated for adhesive bonds with filler based on meshed waste coffee beans at the static and cyclic loading.

\section{Material and methods}

Hybrid adhesive bonds with the composite adhesive layer based on powder filler from waste coffee beans were subject of the research. Adhesive bonds were exposed to a cyclic loading and the service-life was evaluated after 1000 cycles at various stress degrees. Firstly, mechanical properties were determined at the static test according to standard CSN EN 1465, i.e. the tensile shear strength and elongation at break.

The cyclic loading, resp. cyclic material fatigue is the most destructive form of mechanical stress, where even low force causes delamination of an adhesive and influences mechanical properties and service-life of adhesive bonds $[9,12,29,30]$. Utilization of micro-particle fillers in composite materials is not such effective, as utilization of various fibre types [31-34]. Effective utilization of micro-particle fillers is in field of polymer adhesive bonds, where it can replace classic adhesives [9,30]. A filler added into adhesive creates hybrid composite layer, which commonly increases mechanical properties and service-life of adhesive bond at cyclic loading [9].

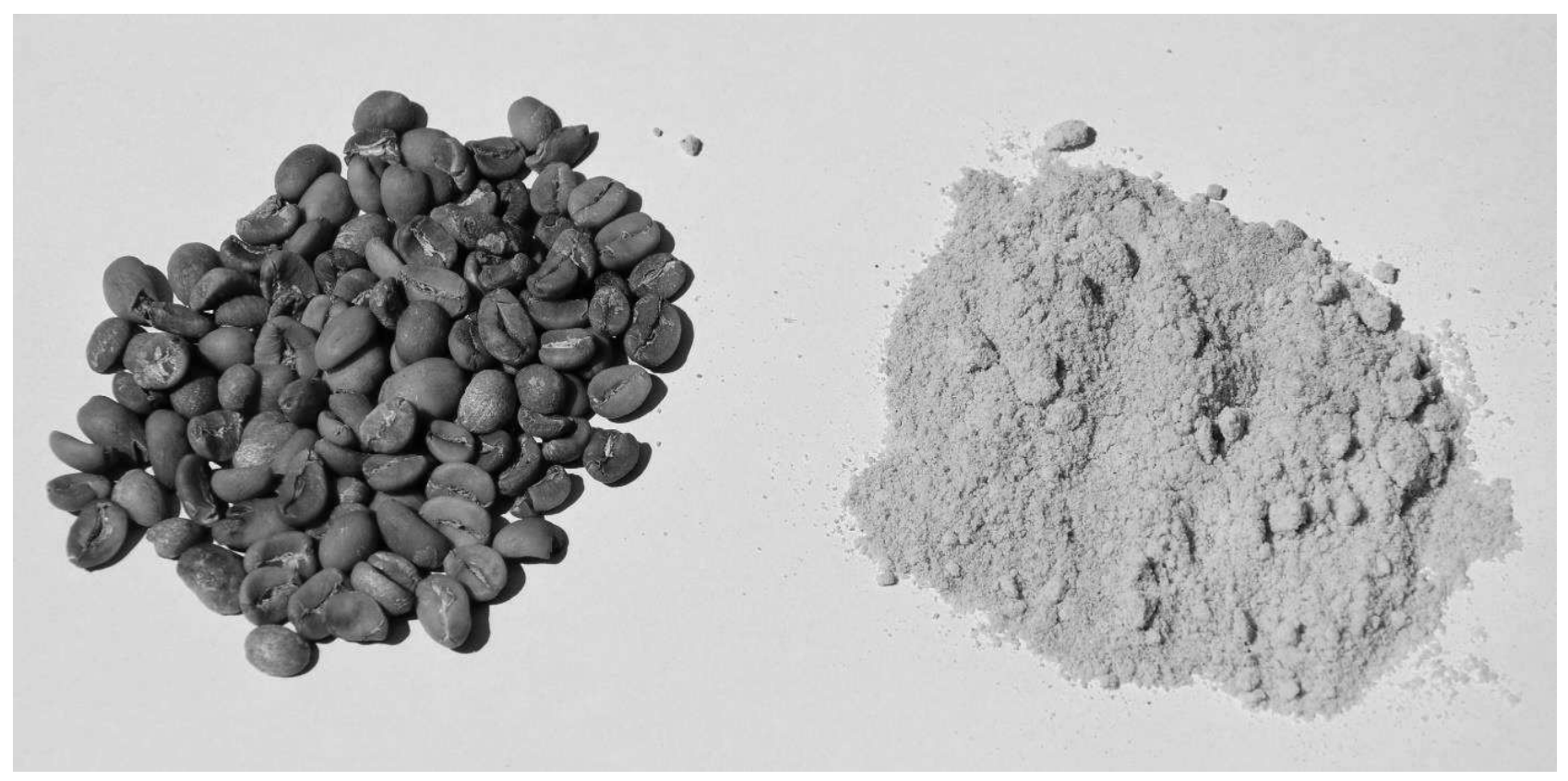

Fig. 1 Waste unroasted coffee beans (left) and powder filler from crusbed waste unroasted coffee beans (right)
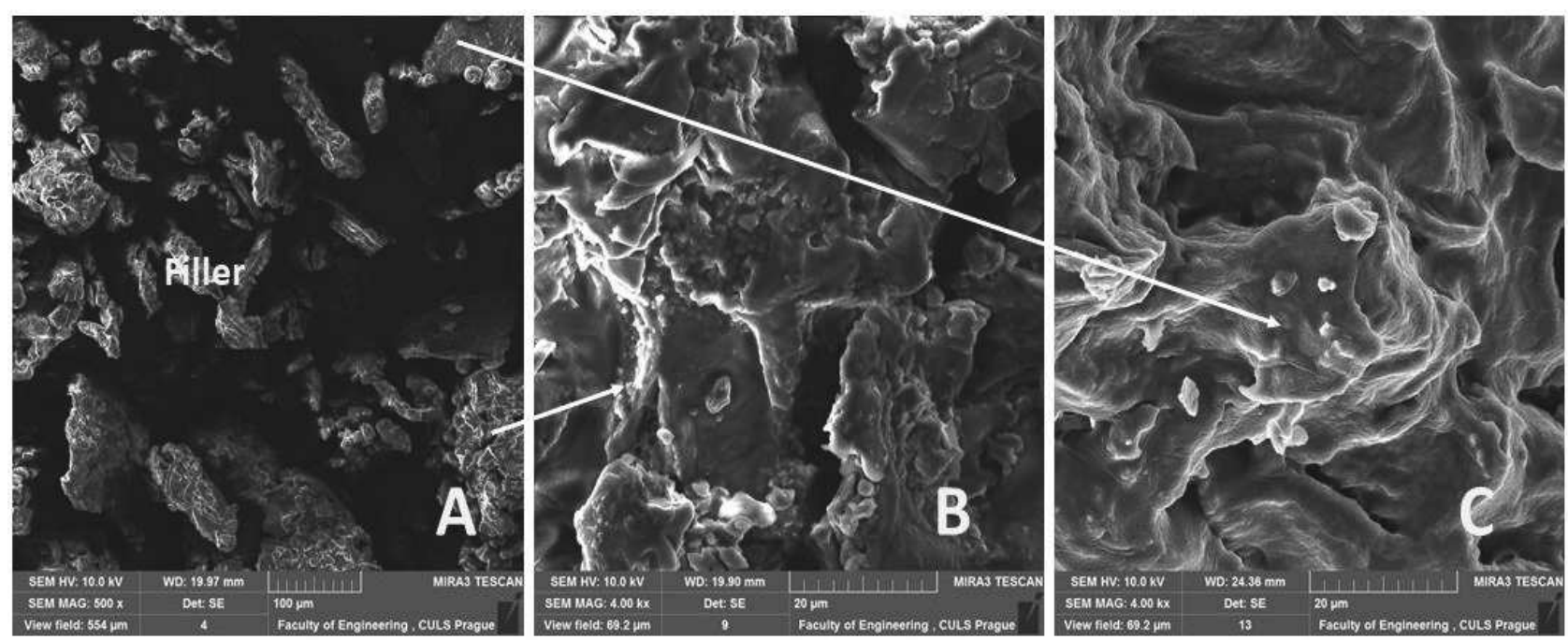

Fig. 2 SEM images of powder filler from crushed waste unroasted coffee beans: A: overall image with shape and size of filler (MAG 500 x), B: detail of filler surface (MAG 4.0 kx), C: detail of filler surface (MAG $4.0 \mathrm{kx}$ ) 
Waste unroasted coffee beans was the filler for polymeric composite. The coffee beans filler was dried out in laboratory chamber at temperature $105 \pm 5{ }^{\circ} \mathrm{C}$ for 24 hours. The coffee beans filler was crushed to individual fraction on oscillating mill Retsch MM400. The waste unroasted beans are evident on Fig. 1 (right), which was used as material for filler production (Fig. 1 - left). The particle size was measured by laser particle analyser Horiba LA-960VA. The powder filler from crushed waste coffee beans contained various fraction size particles not exceeding $100 \mu \mathrm{m}$. Particle analysis results were obvious that significant part $60.3 \%$ of particles has size interval between 20 to 60 $\mu \mathrm{m}$. The filler under $20 \mu \mathrm{m}$ was in part $12.3 \%$.

The waste coffee beans filler and cross-section of adhesive single lap bonds were evaluated on electron microscope MIRA 3 Tescan GMX SE. The measured samples were gold dusted in device Quorum Q150R ES. The powder filler based on waste unroasted coffee beans are evident on Fig. 2.

Adhesive bonds were created by structural twocomponent epoxy resin CHS Epoxy 324 with hardener P11. The epoxy resin was used as the matrix and the powder coffee beans filler was added into. The composite material was mixed on device Phoenix Instrument RSO40D. The ratios and designation of each composite adhesive are evident in Tab. 1.

The adhesive bonds were created according to CSN EN 1465 (Fig. 3). The adhesive bonds hardened at laboratory temperature $\left(22 \pm 2{ }^{\circ} \mathrm{C}\right)$ for 48 hours at loading $750 \mathrm{~g}$.

The adherend was structural carbon steel S235J0 with size $100 \times 25 \times 1.5 \mathrm{~mm}$ according to standard CSN EN 1465 [35]. The adherend surface was mechanically treated in blasting chamber by abrasive Garnet MESH 80 and chemically cleaned by acetone. The roughness of the adherend surface was measured ( $R$ a $1.62 \pm 0.15$ $\mu \mathrm{m}, \mathrm{Rz} 9.21 \pm 0.46 \mu \mathrm{m}$ ) with profile-meter Mitutovo Surftest 301. Construction of adhesive bond is evident on Fig. 3, i.e. bonded steel material (adherend) and adhesive layer. Adhesive bond is according to standard CSN EN 1465. The research evaluated adhesive bonds, which are characterized in Tab. 1.

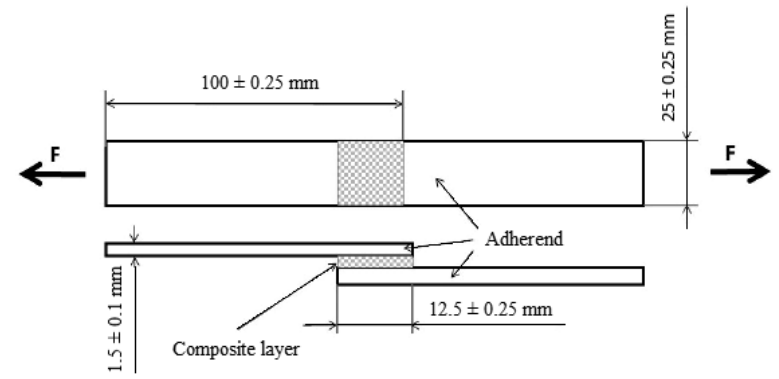

Fig. 3 Adhesive bond according to CSN EN 1465 [35] with notification of adhesive layer, overlap length and direction of loading force during testing on universal testing machine [30]
Tab. 1 Variants of tested adhesive bonds Designation Characteristics

$\begin{array}{cc}\text { ABCF0 } & \begin{array}{c}\text { Adhesive bond without coffee filler } \\ \text { Adhesive bond with coffee filler } \\ \text { ABCF2 }\end{array} \\ \text { (mass ratio 10:2) } & \text { Adhesive bond with coffee filler } \\ \text { (mass ratio 10:3) }\end{array}$

The mechanical properties at static and cyclic test were established on universal testing machine LABTest $5.50 \mathrm{ST}$ with sensor AST KAF $50 \mathrm{kN}$. The testing was at laboratory temperature and loading speed 0.6 $\mathrm{mm} . \mathrm{min}-1$. The loading speed was the same for static and cyclic test. Results of static test were used as the reference value for determination of loading interval for cyclic testing. The cyclic testing was performed to 1000 cycles at the first loading interval 5 to $30 \%$ of static shear tensile strength, i.e. from 165 to $989 \mathrm{~N}$. The second loading interval was 5 to $70 \%$ of static shear tensile strength, i.e. from 165 to 2307 N. After reaching 1000 cycles, testing continued until destruction of the adhesive bonds. If the adhesive bond did not resist 1000 cycles, the number of cycles that the adhesive bonds resisted was recorded. The inertia between each cycle was $0.5 \mathrm{~s}$ on lower loading value, i.e. $165 \mathrm{~N}$.

Measured values were statically tested according to ANOVA F-test on significant level 0.05. Statically nonsignificant difference of tested set of values is at $\mathrm{p}$ $>0.05$ and statistically significant difference of tested set of values is at $\mathrm{p}<0.05$, i.e. variants of experiments.

\section{Results}

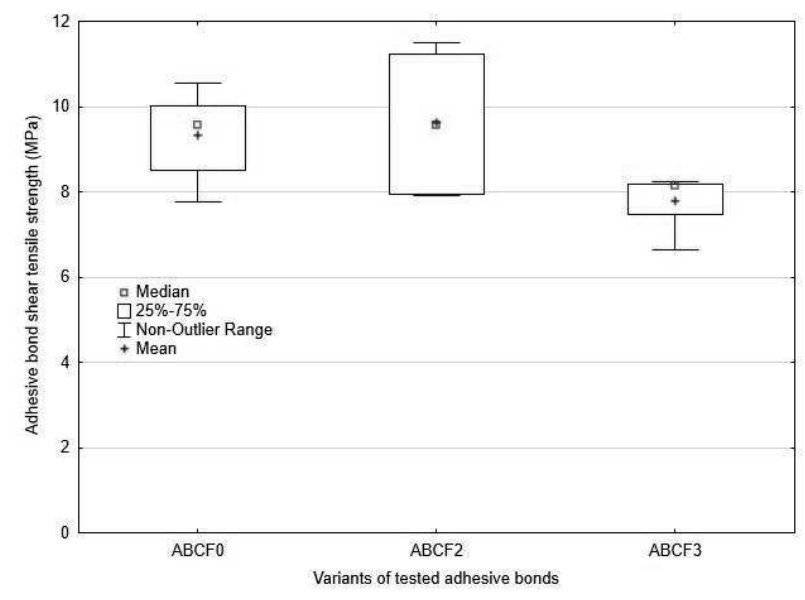

Fig. 4 Static test of single lap adhesive bond - Shear tensile strength

The results of adhesive bonds evaluation at the static test according to CSN EN 1465 are evident from Fig. 4 (Shear tensile strength) and Fig. 5 (Elongation at break). Fig. 4 presents average shear tensile strength 
$9.33 \pm 0.94 \mathrm{MPa}$ of the adhesive bond $\mathrm{ABCF} 0$ at the static tensile test. A slight increase of shear tensile strength $(9.62 \pm 1.41 \mathrm{MPa})$ appeared at the adhesive bonds ABCF2. Higher concentration of the filler caused a decrease of shear tensile strength on $7.80 \pm$ $0.58 \mathrm{MPa}$ at adhesive bonds ABCF3. In terms of statistical testing, this is a significant difference of shear tensile strength between tested variants of experiments, i.e. $\mathrm{ABCF} 0, \mathrm{ABCF} 2$ and $\mathrm{ABCF} 3(\mathrm{p}=0.0299)$.

Fig. 5 presents the results of elongation at break. Elongation at break at adhesive bonds $\mathrm{ABCF} 0$ was $2.68 \pm 0.70 \%$ and at ABCF2 $2.68 \pm 0.67 \%$. Elongation at break of adhesive ABCF3 rapidly decreased on $1.93 \pm 0.24 \%$ with the increasing filler concentration. In terms of statistical testing, this is a nonsignificant difference of elongation at break between tested variants of experiment, i.e. $\mathrm{ABCF} 0, \mathrm{ABCF} 2$ and $\mathrm{ABCF} 3$ $(p=0.0908)$. The statistical testing of measured values did not prove difference between each variants of experiment on significant level 0.05 .

The cross-section of adhesive bond is evident on Fig. $6 \mathrm{~A}$, where the hybrid layer of adhesive bond is noticeable. The detailed view (Fig. 6 B, C) presents interaction between hybrid layer and bonded material and secondly between the filler and matrix. The adhesive bonds characterized good wettability of the bonded material, adhesive and filler. A porosity of the filler is evident on Fig. 6 B and C.

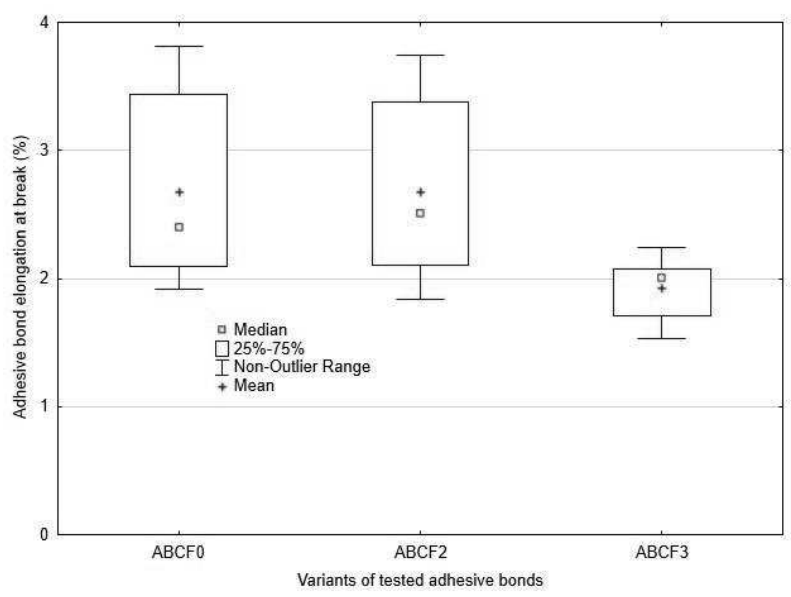

Fig. 5 Static test of single lap adhesive bond - Elongation at break
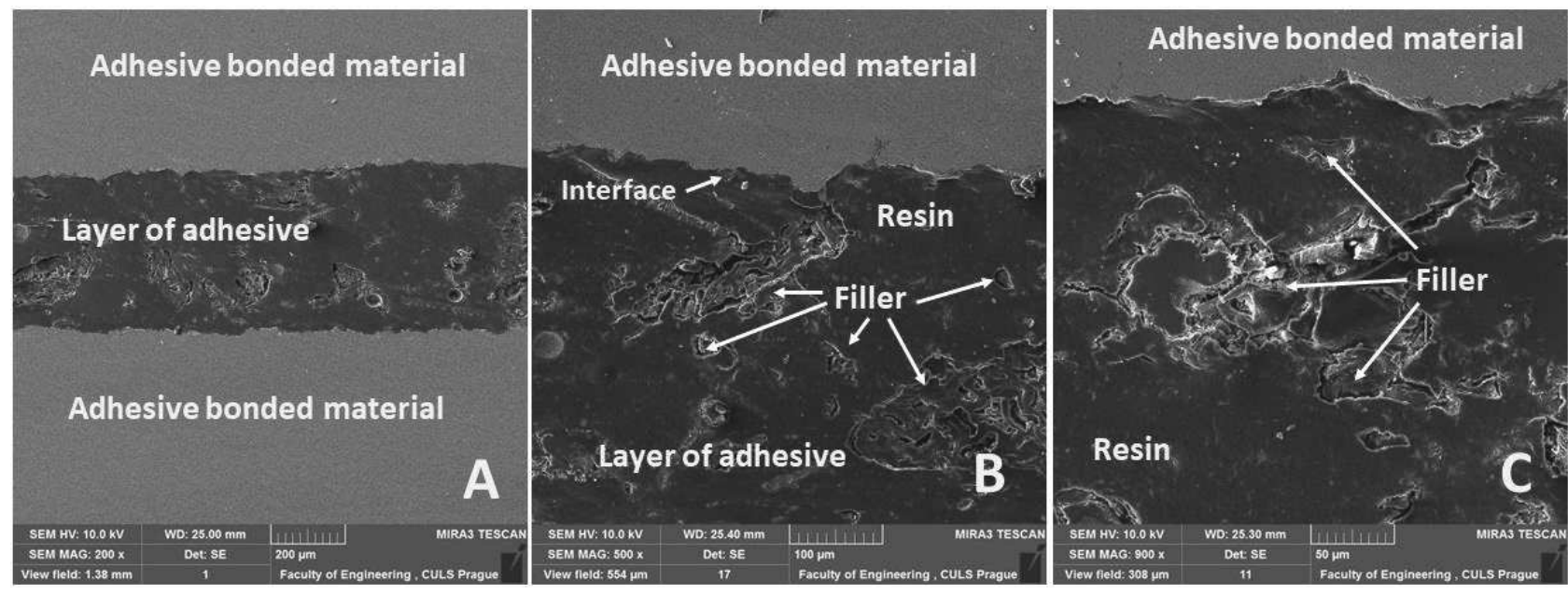

Fig. 6 SEM images of adhesive bond $A B C F 3$ cross-section: A: overall view on cross-section of adhesive bond (MAG 200x), B: detailed view on interaction of adhesive bond and hybrid adhesive layer $(M A G 500 x)$, C: detailed view on interaction of adhesive bonds and hybrid adhesive layer (MAG $900 x$ )

Results of the quasi-static test after 1000 cycles are evident on Tab. 2, where low deformation is noticeable at cyclic loading between $5-30 \%(165-989 \mathrm{~N})$ in the adhesive layer, i.e. the adhesive layer did not change during the loading. A significant change was at adhesive bond $\mathrm{ABCF} 02$. The relative deformation changed between first and last cycle at cyclic loading in interval $1-5 \%$.

A different situation occurred during cyclic loading between $5-70 \%(165-2307 \mathrm{~N})$, where the deformation in the adhesive layer between first and last cycle was.

The adhesive layer showed viscoelastic behaviour, i.e. creep. The relative deformation changed between first and last cycle in interval 12-15\%.
Gyu-Hyeong Lim et al. [15] reported importance of viscous effects at adhesive bonds. The principle is described as follows: Once released of the load and left to shrink, the adhesive does not contract immediately but over a period of time. Achieved by plastic deformation and viscosity, the temporal residual strain in the unloaded specimen facilitates the subsequent deformation of the adhesive material in the next cycle [15].

The quasi-static test showed increase of the adhesive bond strength up to $12 \%$ with flexible adhesive against a tough adhesive [15,36]. Research reported that first deformation occurred in adhesive $[9,15]$. This deformation inside of adhesive and on interface of adhesive bond is presented on Fig. 7. Increasing strength 
of adhesive bond can be caused by elastic behaviour of adhesive layer [9,15,30,37].

Tab. 2 presents a difference in number of adhesive bonds which resisted all 1000 cycles. Adhesive bonds ABCF3 did not resist the cycles of quasi-static test in interval 165 to $2307 \mathrm{~N}$. Tab. 3 shows that the strength of adhesive bonds $\mathrm{ABCF} 0$ was $7.75 \pm 0.58 \mathrm{MPa}$ at the quasi-static test in interval $5-30 \%$. The filler of powder from waste coffee beans did not influence positively on the strength and number of finished cycles.
Only two adhesive bonds ABCF2 resisted the quasistatic test in interval 5-70\%.

Results of the quasi-static test reported that cyclic loading of adhesive bond with higher value of loading force $2307 \mathrm{~N}$ (static tensile test $3296 \pm 343 \mathrm{~N}$ ) led to premature failure of adhesive bond. Same results were achieved in other researches even at lower number of cycles $[9,13,30]$.

Tab. 2 Results of quasi-static test of adhesive bonds

\begin{tabular}{|c|c|c|c|c|c|c|}
\hline $\begin{array}{l}\text { Adhe- } \\
\text { sive } \\
\text { bond }\end{array}$ & $\begin{array}{c}\text { Quasi-static } \\
\text { test }\end{array}$ & $\begin{array}{l}\text { Number of fi- } \\
\text { nished cycles }\end{array}$ & $\begin{array}{l}\text { Relative de- } \\
\text { formation af- } \\
\text { ter } 1 \text { st cycle } \\
\quad(\%)\end{array}$ & $\begin{array}{l}\text { Relative defor- } \\
\text { mation after last } \\
\text { cycle }(\%)\end{array}$ & $\begin{array}{c}\text { Elongation at } \\
\text { break after } 1000 \\
\text { cycles }(\%)\end{array}$ & $\begin{array}{l}\text { Shear tensile } \\
\text { strength after } \\
1000 \text { cycles } \\
(\mathrm{MPa} \text { / Num- } \\
\text { ber of finished } \\
\text { tests (max. 6) }\end{array}$ \\
\hline $\mathrm{ABCF0}$ & \multirow{3}{*}{$\begin{array}{l}5-30 \% \\
165-989 \mathrm{~N}\end{array}$} & $1000 \pm 0$ & $0.14 \pm 0.06$ & $0.15 \pm 0.06$ & $1.78 \pm 0.29$ & $7.75 \pm 0.58 / 6$ \\
\hline $\mathrm{ABCF} 2$ & & $192.2 \pm 362.9$ & $0.25 \pm 0.03$ & $0.30 \pm 0.06$ & $1.1 \pm 0.00$ & $5.70 \pm 0.00 / 1$ \\
\hline $\mathrm{ABCF} 3$ & & $925.0 \pm 167.7$ & $0.32 \pm 0.05$ & $0.34 \pm 0.03$ & $2.00 \pm 0.53$ & $8.05 \pm 2.33 / 5$ \\
\hline $\mathrm{ABCF} 0$ & \multirow{3}{*}{$\begin{array}{l}5-70 \% \\
165-2307 \mathrm{~N}\end{array}$} & $266.3 \pm 169.4$ & $0.35 \pm 0.07$ & $0.50 \pm 0.09$ & 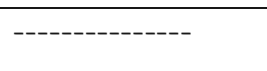 & -----o---- / 0 \\
\hline $\mathrm{ABCF} 2$ & & $484.2 \pm 423.2$ & $0.42 \pm 0.06$ & $0.54 \pm 0.10$ & $2.19 \pm 0.45$ & $8.34 \pm 1.05 / 2$ \\
\hline $\mathrm{ABCF} 3$ & & $0.0 \pm 0.0$ & $0.00 \pm 0.00$ & $0.00 \pm 0.00$ & -------------- & --------------- / 0 \\
\hline
\end{tabular}

The cross-section of adhesive bonds exposed to cyclic loading in 5-70\% (165-2307 N) is evident on Fig. $7 \mathrm{~A}$ and B. A delamination between bonded material and adhesive layer is evident on Fig. $7 \mathrm{~A}$ and B.
This delamination causes premature failure of adhesive bond and decreases service-life of adhesive bond. Delamination of the filler and bonded material is evident on Fig. 7 C.
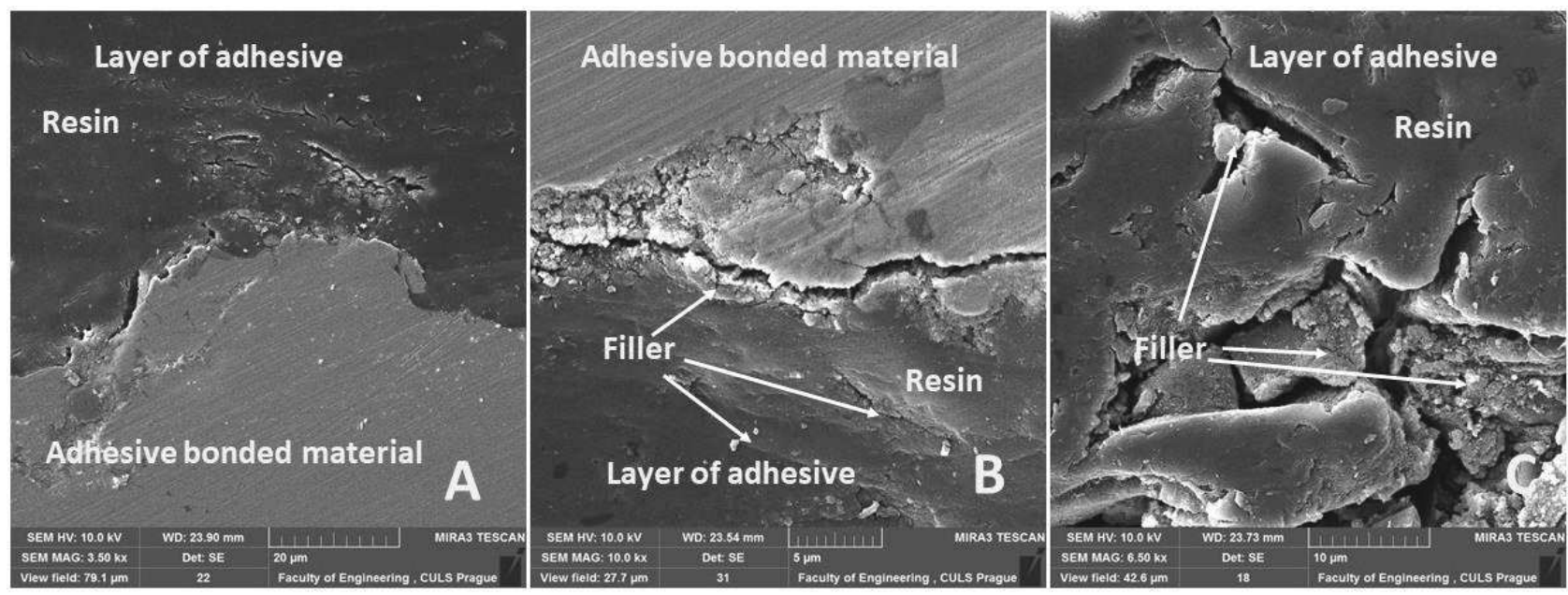

Fig. 7 SEM images of adhesive bond ABCF3 cross-section after quasi-static tests: A: detailed view on interface of adhesive and bonded material (MAG $3.50 \mathrm{kx})$, B: detailed view on interface of adhesive and bonded material (MAG 10.00 kx), C: delamination of bonded material and adhesive (MAG $6.50 \mathrm{kx}$ )

The adhesive bonds ABCF0 have an adhesive type of a fracture surface. Added filler caused change of the fracture type to an adhesively cohesive type (ABCF2 and $\mathrm{ABCF} 3$ ). The adhesively cohesive fracture type on Fig. 7 shows good interaction between the filler of powder waste coffee beans and the adhesive. 

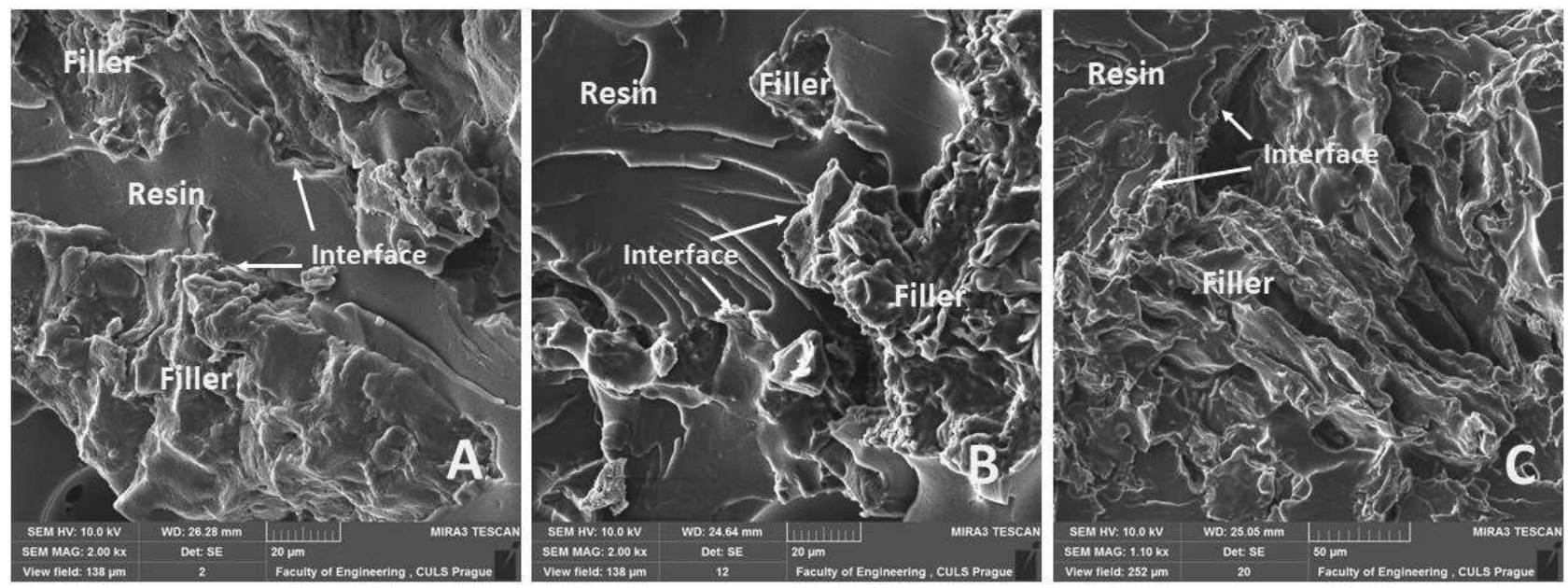

Fig. 8 SEM images of adhesive bond ABCF3 fracture surface: A: static test $A B C F 2$ (MAG 2.00 kx), B: cyclic loading in interval 5-30\%, 165-989 N (MAG 2.00 kx), C: cyclic loading in interval 5-70\%, 165-2307 N (MAG $1.10 \mathrm{kx}$ )

Graphic examples of cyclic loading process of adhesive bond are evident on Fig. 9 and 10 (left). These adhesive bonds were exposed to cyclic loading 5-30\% $(165-989 \mathrm{~N})$ of static shear tensile strength. Fig. 9 (left) presents cyclic loading of adhesive bond without filler which resisted 1000 cycles. Fig. 9 (right) presents cyclic loading of adhesive bond with filler which re-

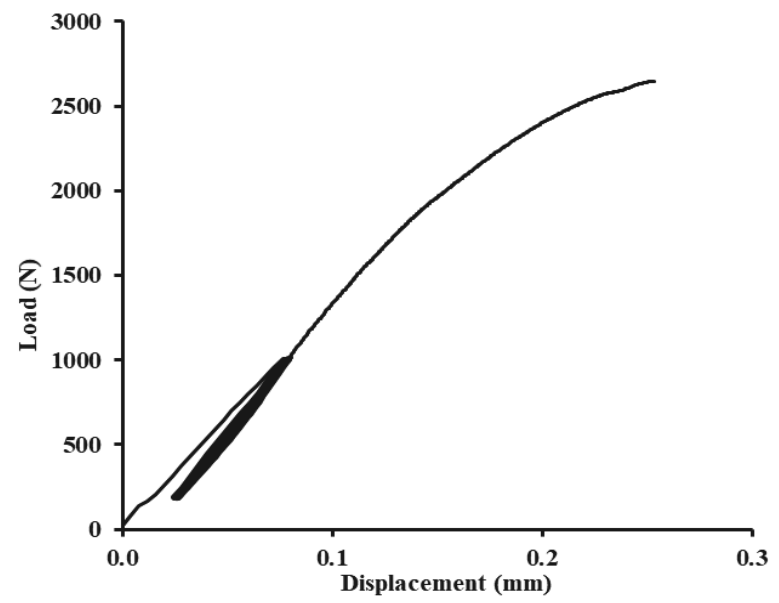

sisted 1000 cycles. Fig. 9 shows continuous of adhesive bond loading after 1000 cycles until to complete destruction. The cyclic loading curve of adhesive bond with filler is shown on Fig. 10 (left) which did not resist 1000 cycles, i.e. the adhesive bond was destructed. The viscoelasticity behaviour of adhesive bonds is not noticeable from the curves.

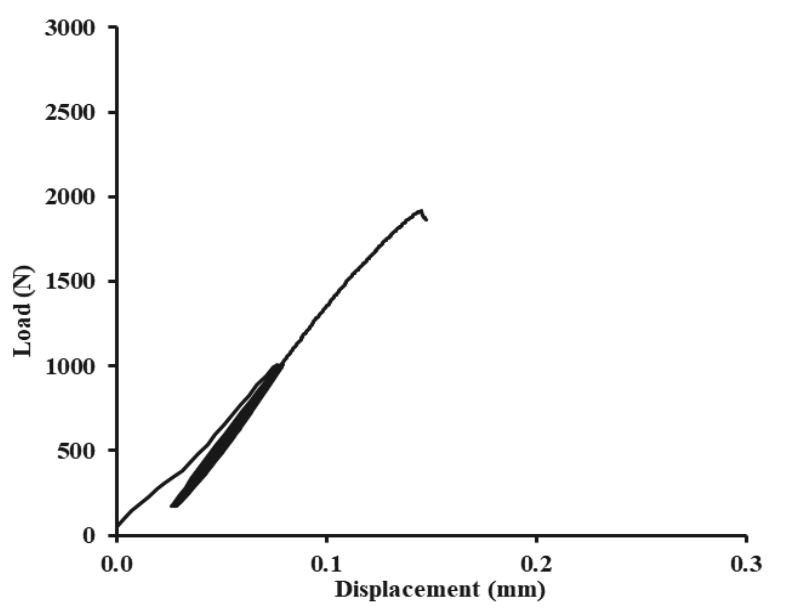

Fig. 9 Cyclic loading with 1000 cycles in interval 5-30\%, 165-989 N of adhesive bond ABCFO (left) and adhesive bond $A B C F 2$ (right)
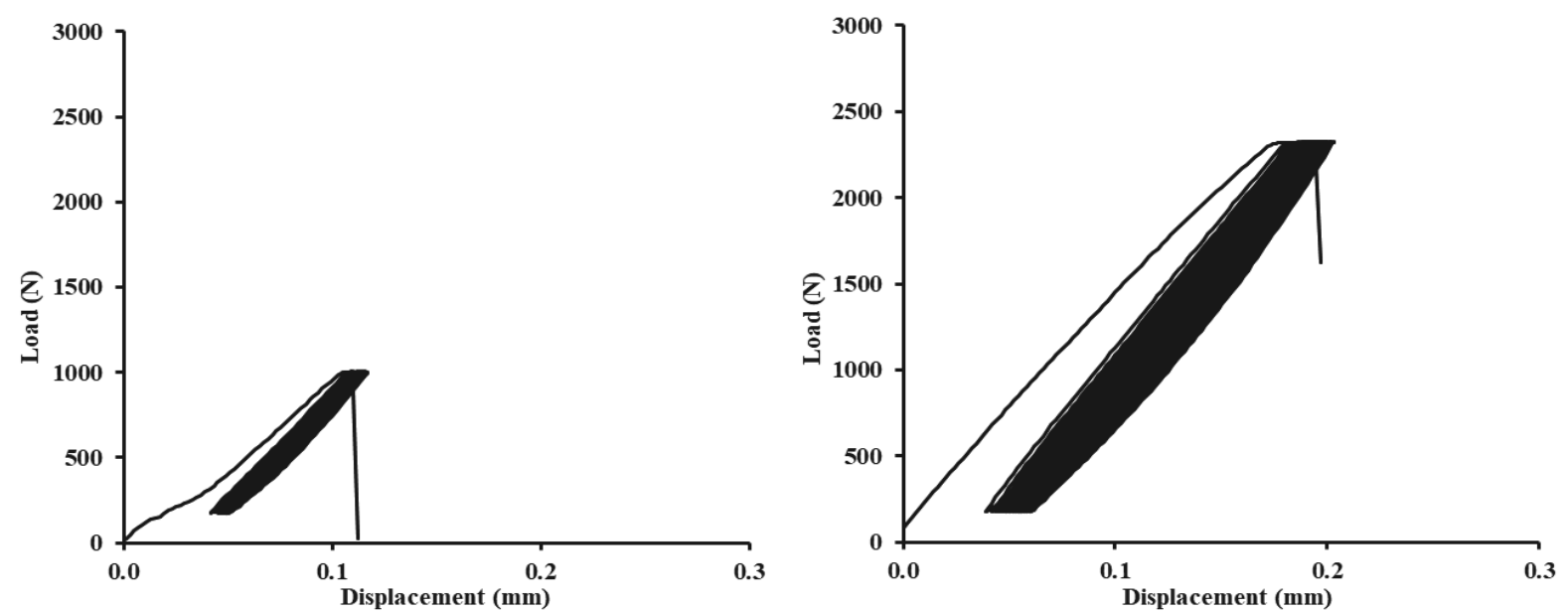

Fig. 10 Cyclic loading of adhesive bond ABCF2 with 76 cycle in interval 5-30\%, 165-989N (left) and adhesive bond ABDF0 with 256 cycles in interval 5-70\%, 165-2307N (right) 
Examples of curves showing cyclic loading of adhesive bonds in interval 5-70\% (165-2307 N) of static shear tensile strength are evident on Fig. 10 to 11 . The viscoelasticity behaviour is noticeable from the curves, i.e. between first and last cycle. The set of 1000 cycles was not reached at adhesive bonds presented on Fig.

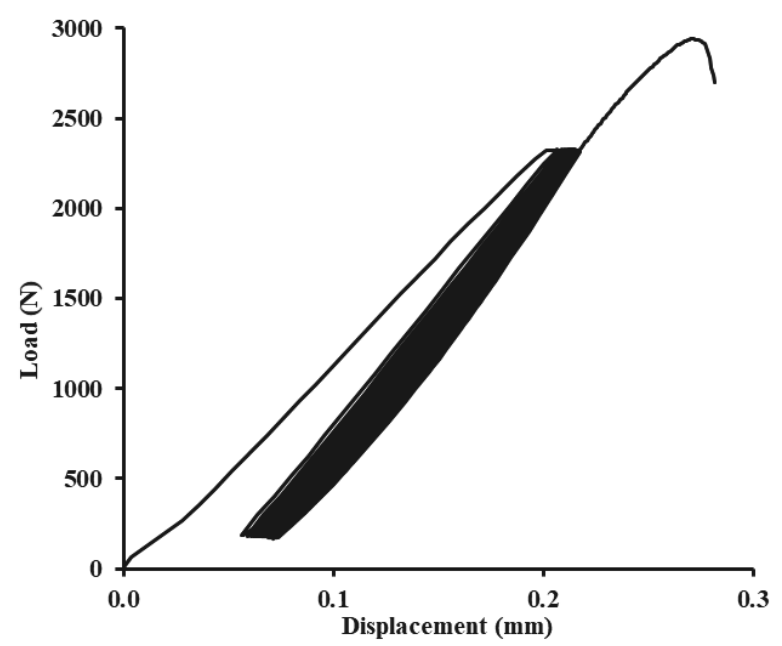

Fig. 11 Cyclic loading of adhesive bond ABCF2 in interval 5-70\%, 165-2307 N with 1000 cycles (left) and with 264 gycles

(right)

\section{Conclusions}

The paper deals with research of adhesive bonds with the hybrid adhesive layer from epoxy matrix reinforced by coffee bean powder, which were exposed to static and cyclic loading with 1000 cycles in interval from 5 to $30 \%$ and at second series from 5 to $70 \%$ of static shear tensile strength. The following conclusions can be determined from the results of the experiments:

- The static tests of adhesive bonds ABCF2, there was a slight increase of shear tensile strength up to $3 \%$ and elongation at break did not increase. Adhesive bonds ABCF3 with higher filler concentration of coffee bean powder, there was a decrease up to $16 \%$ of the shear tensile strength and up to $28 \%$ of elongation at break.

- SEM analysis proved good interaction of bonded material and adhesive layer. The hybrid adhesive layer had good wettability between the filler from coffee bean powder and epoxy resin.

- A significant deformation did not occur between first and last cycle during cyclic loading in $5-30 \%(165-989 \mathrm{~N})$ of static shear tensile strength in the adhesive layer. On the other side, there was significant deformation of the
10 (right) and 11, i.e. premature failure of adhesive bonds occurred. Fig. 11 (left) presents cyclic loading of adhesive bond with the filler which resisted 1000 cycles and then loading until destruction of adhesive bond.

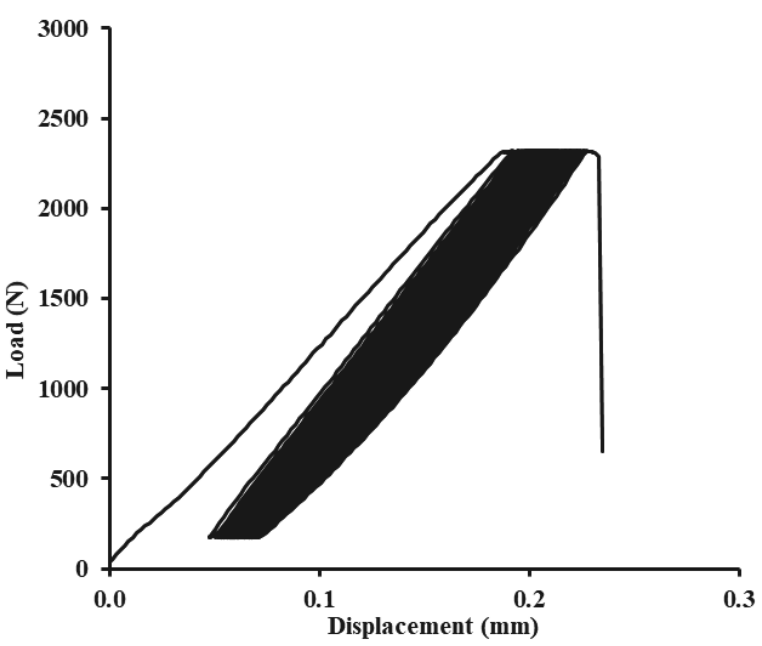

adhesive layer during cyclic loading in 5-70\% (165-2307 N) of static shear tensile strength, i.e. viscoelasticity behaviour (up to $15 \%$ ) of the adhesive bond. SEM analysis results proved that cracks occurred during cyclic loading inside of adhesive layer and on interface bonded material/adhesive. The added filler did not positively influence the number of finished cycles and strength.

- It is obvious from the results of quasi-static test that repeated cyclic loading of the adhesive bond at higher value of loading force leads to premature failure of the adhesive bond.

\section{Acknowledgement}

Supported by International Grand Agency of Faculty of Engineering, Czech University of Life Sciences (no. 2020:31140/1312/3107).

\section{References}

[1] RUDAWSKA A. (2015). Influence of the thickness of joined elements on lap length of aluminium alloy sheet bonded joints. In: Advances in Science and Technology Research Journal, Vol. 9, No. 27, pp. 35. 
[2] RUDAWSKA A., BOCIAGA E., OLEWNIKKRUSZKOWSKA E. (2017). The effect of primers on adhesive properties and strength of adhesive joints made with polyurethane adhesives. In: Journal of adhesion science and technology, Vol. 31, pp. 327-344.

[3] MITURSKA I., RUDAWSKA A., MÜLLER M., VALÁŠEK P. (2020). The Influence of Modification with Natural Fillers on the Mechanical Properties of Epoxy Adhesive Compositions after Storage Time. In: Materials, Vol. 13, pp. 291.

[4] MÜLLER, M., VALÁŠEK, P., RUDAWSKA, A. (2017). Mechanical properties of adhesive bonds reinforced with biological fabric. In: Journal of adhesion science and technology, Vol. 31, No. 17, pp. 1859-1871. ISSN: 0169-4243.

[5] RUDAWSKA A., WAHAB M.A., MÜLLER M. (2020). Effect of ageing process on mechanical properties of adhesive tubular butt joints in aqueous environment. In: International Journal of Adhesion and Adhesives, Vol. 96, pp. 1-11

[6] MÜLLER, M. (2017). Effects of aluminium powder and surface treatment of $\mathrm{AlCu} 4 \mathrm{Mg}$ on mechanical properties of adhesive bond strength. In: Manufacturing Technology, Vol. 17, No. 1, pp. 66-71. ISSN: 1213-2489.

[7] VALÁŠEK, P., MÜLLER, M. (2013). Changes of Polyurethane Mechanical Properties Filled with Glass Powder. In: Manufacturing Technology, Vol. 13, No. 4, pp. 563-568. ISSN: 1213-2489.

[8] MACHADO, J.J.M., NUNES, P.D.P., MARQUES, E.A.S., DA SILVA, L.F.M. (2019). Adhesive joints using aluminium and CFRP substrates tested at low and high temperatures under quasi-static and impact conditions for the automotive industry. In: Composites Part B, Vol. 158, pp. 102-116.

[9] MÜLLER, M., VALÁŠEK, P., KOLÁŘ, V., ŠLEGER, V., KAGAN GÜRDIL, G., HROMASOVA, M., HLOCH, S., MORAVEC, J., PEXA, M. (2019). Material Utilization of Cotton Post-Harvest Line Residues in Polymeric Composites. In: Polymers, Vol. 11, No. 7, pp. 1106, ISSN: 2073-4360.

[10] HAFIZ, T.A., ABDEL WAHAB, M.M., CROCOMBE, A.D., SMITH, P.A. (2010). Mixed-mode fracture of adhesively bonded metallic joints under quasi-static loading. In. Eng. Fract. Mech., Vol. 77, pp. 3434-3445.
[11] KELLY, G. (2006). Quasi-static strength and fatigue life of hybrid (bonded/bolted) composite single-lap joints. In: Compos. Struct., Vol. 72, pp. 119-129.

[12] ŠLEGER, V., MÜLLER, M. (2016). Low-cyclic fatigue of adhesive bonds. In: Manuf. Technol., Vol. 16, pp. 1151-1157.

[13] BROUGHTON, W. R. (1999). Project PAJ3Combined cyclic loading and hostile environments 1996 1999. Report no 19. Project PAJ3.

[14] MESSLER, R.W. (2004). Joining of materials and structures: from pragmatic process to enabling technology. Elsevier; ISBN 9780750677578.

[15] LIM, G. H., BODJONA, K., RAJU, K. P., FIELDING, S., ROMANOV, V., LESSARD, L. (2018). Evolution of mechanical properties of flexible epoxy adhesives under cyclic loading and its effects on composite hybrid bolted/bonded joint design. In: Composite Structures, Vol. 189, pp. 54-60.

[16] REIS P.N., FERREIRA J.A.M, ANTUNES F. (2011). Effect of adherend's rigidity on the shear strength of single lap adhesive joints. In: Int J Adhesion Adhes., Vol. 31, No. 4, pp. 193201.

[17] RAYKHERE, S.L., KUMAR, P., SINGH, R., PARAMESWARAN, V. 2010. Dynamic shear strength of adhesive joints made of metallic and composite adherents. In: Mater Des., Vol. 31, No. 4, pp. 2102-9.

[18] SUADUANG, N., ROSS, S., ROSS, G.M., PRATUMSHAT, S., MAHASARANON, S. (2019). Effect of spent coffee grounds filler on the physical and mechanical properties of poly (lactic acid) bio-composite films. In. Materials Today: Proceedings, Vol. 17, pp. 2104-2110.

[19] MUNIAPPAN, A., SRINIVASAN, R., SANDEEP, M.S., SENTHILKUMAR, N., SENTHIIL, P.V. (2020). Mode-1 fracture toughness analysis of coffee bean powder reinforced polymer composite. In: Materials Today: Proceedings, Vol. 21, pp. 537-542.

[20] MIZERA, C., HERAK, D., HRABE, P., MULLER, M., KABUTEY, A. (2017). Mechanical Behavior of Ensete ventricosum Fiber Under Tension Loading. In: J. Nat. Fibers, Vol. 14, pp. 287-296.

[21] MÜLLER, M., VALÁŠEK, P., RUDAWSKA, A. (2017). Mechanical properties of adhesive bonds reinforced with biological fabric. In: $J$. Adhes. Sci. Technol., Vol. 31, pp. 1859-1871. 
[22] VALÁŠEK, P., RUGGIERO, A., MÜLLER, M. (2017). Experimental description of strength and tribological characteristic of EFB oil palm fibres/epoxy composites with technologically undemanding preparation. In: Compos. Part B Eng., Vol. 122, pp. 79-88.

[23] TAN, H.S., YU, Y.Z., LIU, L.L., XING, L.X. (2010). Effect of Alkali Treatment of Coir Fiber on Its Morphology and Performance of the Fiber/LLDPE Bio-Composites. In: Adv. Mater. Res., Vol. 139, pp. 348-351.

[24] BAJPAI, S.K., MARY, G., CHAND, N. (2015). The use of cotton fibers as reinforcements in composites. In: Biofiber Reinforcements in Composite Materials. pp. 320-341. Woodhead Publishing, Cambridge, UK.

[25] MÜLLER, M., VALÁŠEK, P., RUGGIERO, A. (2017). Strength characteristics of untreated short-fibre composites from the plant ensete ventricosum. In: BioResources, Vol. 12, pp. 255269.

[26] LU, X., ZHANG, M.Q., RONG, M.Z., SHI, G., YANG, G.C. (2003). Self-reinforced melt processable composites of sisal. In: Compos. Sci. Technol., Vol. 63, pp. 177-186.

[27] DE BRITO, E. B., TIENNE, L. G. P., CORDEIRO, S. B., MARQUES, M. D. F. V., MONTEIRO, S. N. (2020). The influence of steam explosion treatment of green coffee cake on the thermal and mechanical properties of reinforced polypropylene matrix composites. In: Journal of Materials Research and Technology, Vol. 9 , No. 3, pp. 4051-4060

[28] REIS, R. S., TIENNE, L. G., DE HS SOUZA, D., MARIA DE FÁTIMA, V. M., MONTEIRO, S. N. (2020). Characterization of coffee parchment andinnovative steam explosion treatment to obtainmicrofibrillated cellulose as potential compositereinforcement. In: Materials Research and Technology, Vol. 9, No. 3, pp. 9412-9421.

[29] ZAVRTÁLEK, J., MÜLLER, M., ŠLÉGER, V. (2016) Low-cyclic fatigue test of adhesive bond reinforced with glass fibre fabric. In: Agron. Res., Vol. 14, pp. 1138-1146.

[30] KOLÁŘ, V., MÜLLER, M., MISHRA, R., RUDAWSKA, A., ŠLEGER, V., TICHÝ, M., VALÁŠEK, P. (2020). Quasi-Static Tests of
Hybrid Adhesive Bonds Based on Biological Reinforcement in the Form of Eggshell Powder. In: Polymers, Vol. 12, No. 6, pp. 1391.

[31] MITURSKA, I., RUDAWSKA, A., MÜLLER, M., VALÁŠEK, P. (2020). The influence of modification with natural fillers on the mechanical properties of epoxy adhesive compositions after storage time. In: Materials (Basel), Vol. 13, pp. 291.

[32] RUDAWSKA, A., STANČEKOVÁ, D., MÜLLER, M., VITENKO, T., IASNII V. (2020). The Strength of the Adhesive Joints of the Medium-Density Fireboards and Particle Boards with the PVC Film. In: Advances in Science and Technology Research Journal, Vol. 14, No. 1, pp. 58-68.

[33] RUDAWSKA, A., JAKUBOWSKA, P., KOZIŃSKI, A. (2017). Surface free energy of composite materials with high calcium carbonate filler content. In: Polimery, Vol. 62, No. 6, pp. 434-440.

[34] RUDAWSKA, A., HANIECKA, I., JASZEK, M., OSIŃSKA-JAROSZUK, M. (2017). The influence of biochemical modification on the properties of adhesive compounds. In: Polymers, Vol. 9, pp. 442.

[35] International Organization for Standardization. (2009). CSN EN 1465-Adhesives-Determination of Tensile Lap-Shear Strength of Bonded Assemblies. Czech Standardization Institute, Prague, Czech.

[36] LIM, G. H., BODJONA, K., RAJU, K. P., FIELDING, S., ROMANOV, V., LESSARD, L. (2018). Evolution of mechanical properties of flexible epoxy adhesives under cyclic loading and its effects on composite hybrid bolted/bonded joint design. In: Composite Structures, Vol. 189, pp. 54-60.

[37] LOUREIRO, A., DA SILVA, L.F., SATO, C., FIGUEIREDO, M. (2010). Comparison of the mechanical behaviour between stiff and flexible adhesive joints for the automotive industry. In: J. Adhes., Vol. 86, pp. 765-87.

[38] HOANG-NGOC, C.T, PAROISSIEN, E. (2010). Simulation of single-lap bonded and hybrid (bolted/bonded) joints with flexible adhesive. In: Int J Adhes Adhes., Vol. 30, pp. 11729. 